\title{
Сравнительный анализ структуры мезофилла листьев у растений из семейств Juncaceae Juss., Cyperaceae Juss. и Poaceae Barnhart
}

\section{Comparative analysis of the leaf mesophyll structure of plants from the families Juncaceae Juss., Cyperaceae Juss. and Poaceae Barnhart}

\author{
Зверева Г. К. ${ }^{1,2}$ \\ Zvereva G. K. ${ }^{1,2}$ \\ ${ }^{1}$ Новосибирский государственный педагогический университет, г. Новосибирск, Россия. E-mail: labsp@ngs.ru \\ ${ }^{2}$ Сибирский федеральный научный центр агробиотехнологий РАН, пос. Краснообск, Россия \\ ${ }^{1}$ Novosibirsk State Pedagogical University, Novosibirsk, Russia \\ ${ }^{2}$ Siberian Federal Scientific Center of Agro-Bio Technologies of the Russian Academy of Sciences, Krasnoobsk, Russia
}

\begin{abstract}
Peферат. Проведено сравнительное изучение клеточной организации мезофилла листовых пластинок растений из семейств Јuncaceae, Суреraceae и Роасеае. Показано, что ассимиляционная паренхима растений семейств Juncaceae и Cуреraceae состоит из клеток простой формы. Лишь у некоторых видов растений в глубине мезофилла имеются лопастные клетки, близкие к таковым у злаков. В листьях растений Роасеае широко распространены клетки сложной ячеистой и лопастной формы, у многих видов отмечаются и более усложнённые клеточные конфигурации. Рассмотрены особенности строения и основные адаптации дифференцированного и недифференцированного мезофилла листьев растений к световому режиму.
\end{abstract}

Ключевые слова. Анатомия, клетки простой формы, клетки сложной формы, однодольные растения, структурная организация мезофилла.

Summary. A comparative study of the cellular organization of the mesophyll of leaf blades of plants from the families Juncaceae, Cyperaceae and Poaceae was carried out. It is shown that the assimilative parenchyma of plants of families Juncaceae and Cyperaceae consists of cells of simple form. Only in some plant species, in the depth of the mesophyll, there are lobes cells similar to those in grasses. In the leaves of Poaceae plants are widely distributed cells of a complex cellular and lobed form and in many species are observed more complex cell configurations. The structural features and main adaptations of the differentiated and undifferentiated mesophyll of plant leaves to the light regime are considered.

Key words. Anatomy, simple form cells, complex-shaped cells, monocotyledonous plants, spatial organization of mesophyll.

\section{Введение}

Мезофилл листьев однодольных растений обычно описывают как недифференцированный, реже выделяют палисадную и губчатую паренхимы (Имс, Мак Даниэльс, 1935; Раздорский, 1949; Кардашевская, 2003 и др.). В то же время в ассимиляционной ткани многих однодольных растений из разных семейств отмечают наличие клеток сложной формы, отличающихся выраженными выростами и складками (Крашенинников, 1937; Chonan, 1965; Fritsch, 1988; Oliveira et al., 2015 и др.). Широкое присутствие клеток сложных конфигураций наблюдается у представителей семейства Poaceae Barnhart (Haberlandt, 1928; Kaufman, 1959; Tuan, 1962 и др.). Нами рассмотрены особенности клеточной организации мезофилла листьев злаков с простыми и сложными формами клеток (Зверева, 2007, 2009).

Задачей настоящей работы было дать сравнительно-анатомический анализ строения мезофилла в листьях растений из семейств Роасеае, Суреraceae Juss. и Juncaceae Juss.

По системе А. Л. Тахтаджяна семейство Роасеае представляет порядок Poales, а семейства Cyperaceae и Juncaceae включены в порядок Juncales (Takhtajan, 2009). В системе «группы филогении по- 
крытосеменных» (Angiosperm phylogeny group - APG), основанной на генетических признаках, эти семейства объединены в порядок Poales (The Angiosperm Phylogeny Group, 2016).

\section{Методы исследования}

Структура мезофилла листовых пластинок рассмотрена у 77 видов растений из семейств Роасеae, Cyperaceae и Јuncaceae, относящихся к 51 роду (табл. 1). Строение мезофилла и основные проекции клеток изучены на мацерированных препаратах, а также на поперечных и продольных срезах листьев, фиксированных в смеси Гаммалунда (Possingham, Saurer, 1969, Гродзинский, Гродзинский, 1973). Листья отбирались в средней части генеративных побегов, находящихся в состоянии бутонизации и начала цветения. При характеристике мезофилла будем опираться на предложенную нами ранее классификацию конфигураций клеток и схему их расположения в листовом пространстве злаков (Зверева, 2009).

Таблица 1

Число изученных видов растений

\begin{tabular}{|c|c|c|}
\hline \multirow{2}{*}{ Семейство } & \multicolumn{2}{|c|}{ Число } \\
\cline { 2 - 3 } & родов & видов \\
\hline Cyperaceae & 4 & 8 \\
\hline Juncaceae & 2 & 4 \\
\hline Poaceae & 45 & 65 \\
\hline
\end{tabular}

\section{Результаты исследований и обсуждение}

У рассматриваемых однодольных растений листья с параллельным жилкованием, состоящие из листовых пластинок и листовых влагалищ. Мезофилл сосредоточен между сосудисто-волокнистыми пучками, при этом у растений увлажнённых местообитаний наблюдается развитие воздухоносных полостей.

Более подробно нами рассмотрена пространственная организация ассимиляционной паренхимы в листьях злаков, мезофилл которых сложен как из клеток простой (вытянутых или округлых, иногда со слабой извилистостью), так и сложной (с хорошо выраженными выростами и складками) формы (Зверева, 2009). У большинства изученных видов клетки мезофилла имеют сложные ячеистые и лопастные конфигурации разной степени выраженности. Ячеистые клетки расположены вдоль листа и могут быть ориентированы своими секциями как перпендикулярно листовой поверхности (ячеистые клетки первой группы), так и параллельно (ячеистые клетки второй группы). Клетки лопастной формы, расположенные в глубине хлоренхимы, отличаются разнообразными выростами и складками, проявляющимися на поперечных срезах. Структурную основу мезофилла листьев злаков создают эти три группы клеток, которые своими наибольшими проекциями располагаются во взаимно перпендикулярных направлениях. У злаков, мезофилл которых состоит в основном из клеток простой формы, первая группа клеток представлена более или менее выраженными палисадными, а вторая - округлыми или губчатыми клетками. По аналогии с двудольными растениями ячеистые клетки первой группы приближаются к палисадной паренхиме, ячеистые клетки второй группы более близки к губчатой ткани. Лопастные клетки, названные нами срединными, своими узкими овалами, обращёнными к поверхности листа, могут усиливать палисадную паренхиму, но чаще, совместно с клетками второй группы, формируют губчатую ткань.

На продольных сечениях листьев ассимиляционные клетки расположены параллельными рядами относительно сосудисто-волокнистых пучков, при этом экологические возможности произрастания растений во многом зависят от расположения клеток мезофилла по отношению к листовым поверхностям, и, в первую очередь, к абаксиальной эпидерме. Так, у злаков влажных и затенённых местообитаний часто наблюдается выраженная дифференциация рядов клеточных проекций, как по форме, так и по размерам. У ксерофитов и большей части мезофитов эти проекции более однообразные, округлые или чуть овальные, что отражает развитие палисадной ткани, образованной ячеистыми клетками первой группы или простыми вытянутыми клетками. 
В мезофилле изученных видов из семейств Јuncaceae и Суреraceae клетки сложной ячеистой формы не обнаружены. Сложные дольчатые и лопастные клетки, наибольшими проекциями раскрывающиеся на поперечных сечениях, отмечены внутри воздухоносных полостей листовых пластинок Bolboschoenus planiculmis (Fr. Schmidt) Egor. и Juncus compressus Jacq. (Зверева, 2018а).

Ассимиляционная ткань у представителей рода Carex L. сложена преимущественно из овальных клеток, вытянутых поперёк листа. На парадермальных срезах их проекции расположены рядами вдоль листа и обращены к эпидермам более или менее узкими плотно сомкнутыми овалами, что в какой-то мере приближает их к столбчатой ткани. Подобные клетки цилиндрической формы, опирающиеся длинной осью на эпидерму, часто встречаются и у злаков гигрофитов и гигромезофитов, по размерам они оказались близки к осокам (табл. 2). В листьях осок, также как и у злаков, нередко у эпидермы наблюдается чередование рядов клеточных проекций, отличающихся по форме и размерам, что указывает на некоторое сходство в строении и отражает сочетание световых и теневых черт в организации их мезофилла.

Таблица 2

Размеры клеток мезофилла первого ряда у абаксиальной эпидермы в листьях растений из семейств Суреraceae, Juncaceae и Poaceae

\begin{tabular}{|c|c|c|c|c|}
\hline \multirow[t]{2}{*}{ Вид } & \multirow[t]{2}{*}{ Семейство } & \multicolumn{3}{|c|}{ Размеры клеток, мкм } \\
\hline & & высота & ширина & толщина \\
\hline \multicolumn{5}{|c|}{ Палисадные клетки и секции ячеистых клеток первой группы } \\
\hline Bolboschoenus planiculmis (Fr. Schmidt) Egor. & Cyperaceae & $34,0 \pm 1,40$ & $15,7 \pm 0,88$ & $12,6 \pm 0,35$ \\
\hline Juncellus pannonicus (Jacq.) Clarke & Cyperaceae & $17,1 \pm 0,87$ & $12,5 \pm 0,28$ & $12,4 \pm 0,27$ \\
\hline Scirpus lacustris L. & Cyperaceae & $38,4 \pm 2,02$ & $14,2 \pm 0,43$ & $11,8 \pm 0,32$ \\
\hline Juncus compressus Jacq. & Juncaceae & $23,2 \pm 0,38$ & $10,7 \pm 0,43$ & $10,3 \pm 0,27$ \\
\hline Achnatherum splendens (Trin.) Nevski & Poaceae & $25,7 \pm 1,05$ & $11,4 \pm 0,35$ & $12,7 \pm 0,40$ \\
\hline Alopecurus pratensis L. & Poaceae & $40,4 \pm 1,20$ & $25,4 \pm 0,75$ & $20,0 \pm 0,68$ \\
\hline Bromopsis inermis (Leysser & Poaceae & $22,6 \pm 1,15$ & $15,8 \pm 0,88$ & $14,7 \pm 0,30$ \\
\hline Crypsis aculeata (L.) Ait. & Poaceae & $16,7 \pm 0,72$ & $9,7 \pm 0,36$ & $8,4 \pm 0,55$ \\
\hline Elytrigia repens (L.) Nevski & Poaceae & $30,1 \pm 1,70$ & $17,7 \pm 0,88$ & $17,3 \pm 0,35$ \\
\hline Stipa pennata $\mathrm{L}$. & Poaceae & $17,4 \pm 0,42$ & $10,5 \pm 0,32$ & $9,2 \pm 0,15$ \\
\hline \multicolumn{5}{|c|}{ Клетки овальные, вытянутые поперёк листа } \\
\hline Carex diluta Bieb & Cyperaceae & $12,4 \pm 0,52$ & $17,2 \pm 0,55$ & $11,7 \pm 0,28$ \\
\hline C. supina Willd. ex Wahlenb. & Cyperaceae & $12,5 \pm 0,50$ & $17,0 \pm 0,53$ & $10,2 \pm 0,46$ \\
\hline C. acuta $\mathrm{L}$. & Cyperaceae & $12,5 \pm 0,43$ & $18,1 \pm 0,59$ & $14,9 \pm 0,52$ \\
\hline C. pediformis C.A. Mey. & Cyperaceae & $11,8 \pm 0,32$ & $18,5 \pm 0,63$ & $12,5 \pm 0,53$ \\
\hline Alopecurus aequalis Sobol. & Poaceae & $13,4 \pm 0,38$ & $23,2 \pm 0,77$ & $12,7 \pm 0,68$ \\
\hline \multicolumn{5}{|c|}{ Клетки губчатой ткани и ячеистые клетки второй группы } \\
\hline Luzula pilosa (L.) Willd. & Juncaceae & $13,9 \pm 0,30$ & $22,2 \pm 0,77$ & $30,4 \pm 1,10$ \\
\hline Festuca gigantea (L.) Villar & Poaceae & $28,9 \pm 1,52$ & $28,9 \pm 1,15$ & $40,9 \pm 2,00$ \\
\hline Hierochloe odorata (L.) Beauv. & Poaceae & $22,4 \pm 1,20$ & $24,4 \pm 1,12$ & $37,1 \pm 1,44$ \\
\hline
\end{tabular}

Хорошо развитая палисадная паренхима, состоящая из 1-8 рядов вытянутых клеток цилиндрической формы с округлыми или чуть овальными основаниями, наблюдается в родах Scirpus L., Bolboschoenus (Asch.) Palla (сем. Cуреraceae) и Junсиs L. (сем. Juncaceae). Столбчатая ткань размещается как под одной, так и под обеими эпидермами. При этом у многих растений глубоко расположенные ассимиляционные клетки можно рассматривать как губчатые, в основном они имеют прямые стенки, но у представителей более затенённых местообитаний их очертания часто чуть волнистые. Так, мезофилл листовых пластинок лесного растения Luzula pilosa (L.) Willd. (сем. Juncaceae) очень рыхлый, у адаксиальной стороны располагаются преимущественно изодиаметрические клетки, у абаксиальной поверхности наблюдаются крупные плоские клетки весьма разнообразных очертаний, своими основными проекциями они вытянуты вдоль листа. 
Сравнительно-анатомическое изучение мезофилла листьев у однолетних растений Crypsis aculeata (L.) Aiton (Poaceae) и Juncellus pannonicus (Jacq.) Clarke (Cyperaceae) с $\mathrm{C}_{4}$-фотосинтетическим метаболизмом выявило наличие в структуре ассимиляционной ткани у Crypsis aculeata венцовых клеток сложной ячеистой и полуячеистой формы, хлоренхима Juncellus pannonicus образована клетками простых конфигураций (Зверева, 2018б).

Таким образом, в листьях растений из семейств Суреraceae и Јuncaceae мезофилл построен из клеток простой формы. Лишь у отдельных видов отмечаются сложные лопастные клетки во внутренних слоях, по особенностям расположения они близки к срединным клеткам, выделенным нами у злаков. В листьях растений из семейства Роасеае широко распространены клетки сложной ячеистой и лопастной формы, у многих видов злаков встречаются и более усложнённые клеточные конфигурации. Приспособление к световому режиму происходит как за счет формирования более или менее выраженной палисадной и губчатой ткани, что в большей степени характерно для Суреraceae и Јuncaceae, так и за счет выполнения этих функций клетками простых и сложных конфигураций и их сочетанием в пространстве листа с недифференцированным мезофиллом.

\section{ЛИТЕРАТУРА}

Гродзинский А. М., Гродзинский Д. М. Краткий справочник по физиологии растений. - Киев: Наукова думка, 1973. $-591 \mathrm{c}$.

Зверева $\boldsymbol{\Gamma}$. $\boldsymbol{K}$. Особенности расположения клеток хлоренхимы в листовых пластинках злаков // Бот. журн., 2007. - Т. 92, № 7. - С. 997-1011.

Зверева $Г$. К. Пространственная организация мезофилла листовых пластинок фестукоидных злаков (Роасеае) и её экологическое значение // Бот. журн., 2009. - Т. 94, № 8. - С. 1204-1215.

Зверева $\boldsymbol{\Gamma} . \boldsymbol{K}$. Особенности строения мезофилла листьев прибрежно-водных однодольных растений // Растительный мир Азиатской России, 2018а. - № 2 (30). - С. 3-8.

Зверева Г. К. Сравнительно-анатомическое изучение ассимиляционной ткани у Crypsis aculeata (L.) Aiton и Juncellus pannonicus (Jacq.) Clarke с $\mathrm{C}_{4}$-фотосинтетическим метаболизмом // Ученые записки ЗабГУ, 2018б. - Т. 13. - № 1. - С. 6-15.

Имс А. Д., Мак Даниэльс Л. Г. Введение в анатомию растений. - М.-Л.: Сельхозгиз, 1935. - 332 с.

Кардашевская В. E. Злаки. - Якутск: Изд-во Якутского ун-та, 2003. - 180 с.

Крашенинников Ф. Н. Лекции по анатомии растений. - М.-Л.: Гос. изд-во биол. и медицинск. лит-ры, 1937. $-446 \mathrm{c}$.

Раздорский В. Ф. Анатомия растений. - М.: Советская наука, 1949. - 524 с.

Angiosperm Phylogeny Group. An update of the Angiosperm Phylogeny Group classification for the orders and families of flowering plants: APG IV // Botanical Journal of the Linnean Society, 2016. - Vol. 181, № 1. - P. 1-20.

Chonan N. Studies on the photosynthetic tissues in the leaves of cereal crops. 1. The mesophyll structure of wheat leaves inserted at different level of shoot // Tohoku Journal of Agricultural Research, 1965. - Vol. 16. № 1. - P. 1-12.

Fritsch R. M. Anatomical investigation of the leaf blade of Allium L. (Alliaceae) I. Species having one row of vascular bundles // Flora,1988. - Vol.181, Iss. 1-2. - P. 83-100.

Haberlandt G. Physiological plant anatomy. - London, 1928. - 777 p.

Kaufman P. B. Development of the shoot of Oryza sativa L. 2. Leaf histogenesis // Phytomorphology, 1959. - Vol. 9. - P. 277-311.

Oliveira F. M. G., Scatena V. L., Oriani A. Anatomy of vegetative organs and inflorescence axis of Orectanthe sceptrum (Xyridaceae-Poales) // Journal of the Torrey Botanical Society, 2015. - Vol.142, № 3. - P. 258-268.

Possingham J. V., Saurer $\boldsymbol{W}$. Changes in chloroplast number per cell during leaf development in spinach // Planta, 1969. - Vol. 86, № 2. - P. 186-194.

Takhtajan A. Flowering plants. - Springer Science+Business Media, 2009. - 871 p.

Tuan H. C. Studies on the leaf cells of wheat. I. Morphology of the mesophyll cells // Acta Botanica Sinica, 1962. Vol.10. №.4. - P. 291-297. 